\title{
Q\&A: Georgina Ferry on writing biography
}

Acclaimed biographer Georgina Ferry has chronicled the lives of two Nobel prizewinning chemists, Dorothy Hodgkin and Max Perutz. In the fourth in our series of five interviews with authors who each write science books for a different audience, Ferry reveals how detachment is needed to turn an attic's worth of personal letters into a compelling story.

\section{What do you like most about the biography format?}

It has your narrative set out for you because the story has a beginning, a middle and an end. And also there's nosiness. You are given licence to go and read someone's personal letters and enter into their life in a way that you are rarely privileged to do.

\section{What is the purpose of a biography?}

The traditional idea is to show an exemplary life that we might all strive to live up to. But the advantage I see in scientific biography is that it provides a way of getting across to the public how scientists actually live; what doing science is really about.

\section{Is it appropriate to tell the history of science through personal stories?}

Within the history of science, biography has been disparaged for a long time because it puts too much focus on the individual. But that is beginning to change. If you do your biography properly, then you place your subject in context. It is not a question of individual heroes suddenly having some eureka moment.

\section{Why did you choose Dorothy Hodgkin for your first biography? \\ She is the only British woman to have won a science Nobel prize, and yet most people don't even recognize her name. She was a mother who had three kids and a husband who was largely absent throughout her professional career. I was interested in finding out how she negotiated that.}

\section{Its title is Dorothy Hodgkin: A Life. Did you} deliberately avoid science in the title? I wanted it to look like a literary biography, not a science book. When people go into a book shop and browse, they are looking for something familiar. Science can be offputting; if you've got science attached to a name you've never heard of, a person is not necessarily going to pick that book up and buy it.

\section{Who makes a good subject?}

The obvious candidates - Albert Einstein, Charles Darwin, Marie Curie - continue to be good choices because you don't

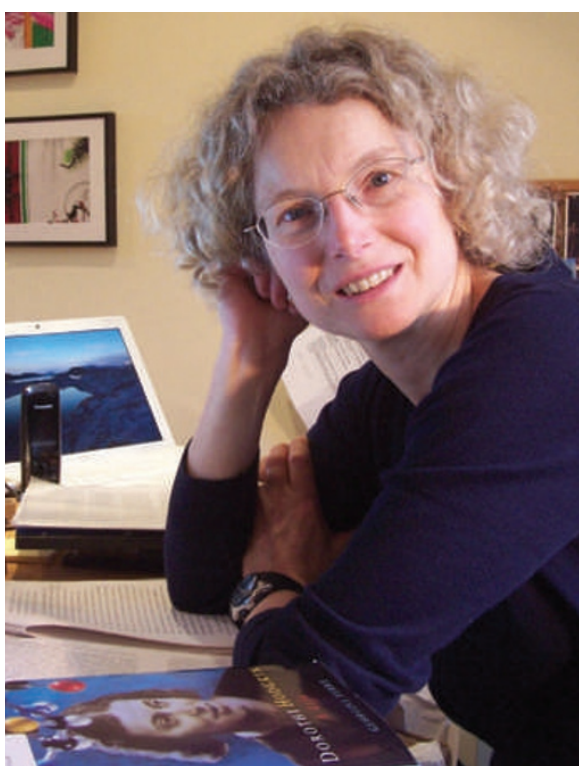

Georgina Ferry: scientists should archive e-mails.

have that initial recognition barrier to get across. You do need them to have reached the pinnacle of something. But that is not enough. If somebody has spent 60 years getting up, going to the lab and coming home, they are not going to be a great subject for a biography. It helps if there is some controversy in their life. Graham Farmelo's prize-winning book on physicist Paul Dirac, The Strangest Man, is fascinating because Dirac was so odd and had such a tragic life.

\section{Do you need the permission of living relatives?}

Biographies can be written without personal authorization, but I could not have done either of my books without the fantastic co-operation of the family members. The Hodgkin family never threw anything away, and they gave me carte blanche to read anything that I could find in the attic. I like to include direct quotes, and you need a family's permission to use that material.

\section{Beyond family records, where do you go?} You can interview living colleagues but archives of professional and personal letters give you the bulk of your source material. You find out where things are, and then you travel around and look at them. Some records are beginning to go up on the Internet, and one day we'll do this research from our desks. But that will take away a bit of the magic.

\section{Is technology affecting archived material} in other ways?

People don't write letters any more in the way that they used to. Scientists should think before they throw away e-mails, and archive anything that might be of interest to an audience in 20,50 or 100 years time. The British Library set up the Digital Lives Research Project to look at this specific problem. [See Nature 459, 775-776; 2009.]

\section{Do you have to step into the shoes of} these people to write about them? Actually you have to retain a certain detachment. You have got to be able to see their flaws as well as their triumphs, and you can't be so close that you feel it would be a betrayal to mention something that they wouldn't want revealed. But you do need to go and look at places where people were, so you can describe them accurately.

\section{How might biographies be structured?} Currently the fashion is against the cradleto-grave biography. Group biographies are popular, such as Richard Holmes's Age of Wonder. If you're determined to look at only one person, find a different way of doing it. A good example is Hermione Lee's biography of writer Virginia Woolf, in which each chapter is thematic.

\section{How much money can an author make?} In my experience, you rarely get enough money to cover the time you spend doing the work. Each of those books took me about four years, working on other projects at the same time. Publishers offer an advance based on how many they think you will sell, perhaps around $£ 10,000-£ 20,000$ [US\$16,000-\$32,000] if you are lucky. So it is a labour of love.

Interview by Nicola Jones, a commissioning editor for Nature's Opinion section.

Georgina Ferry is author of Dorothy Hodgkin: A Life (Granta, 1998) and Max Perutz and the Secret of Life (Chatto \& Windus, 2007). 